\title{
Pemantauan Kondisi Ikan Karang Menggunakan Metode Reef Check Di Perairan Selat Sempu Malang Selatan
}

\author{
Oktiyas Muzaky Luthfi a*, Riza Alifia a, Sherla Rizqia Putri a, Firmina Bethrix Dasi a, \\ Bramastrha Artha Putra a, Davitra Eka Permana a, Elda Pebrizayanti a, \\ Muhammad Zuhal Fikri a, Johan Saputro a, Christopher Ari Setiawan a , Krista Sibuea a, \\ Abdul Razak a \\ a Program Studi Ilmu Kelautan, Fakultas Perikanan dan Ilmu Kelautan, Universitas Brawijaya, Jalan Veteran, Malang, Jawa Timur-Indonesia. \\ * Penulis koresponden. Tel.: +62-813-9010-6790 \\ Alamate-mail: omuzakyl@ub.ac.id
}

Diterima (received) 3 Februari 2017; disetujui (accepted) 10 Juni 2017; tersedia secara online (available online) 18 Juni 2017

\begin{abstract}
Reef Check is an activity to find out the condition of coral reefs and its surrounding ecosystems be then described and categorized its healthiness. The island of Java is one of the Islands in Indonesia that has lots of beaches, especially for East Java, here they have several areas that has become our research site in Sempu Strait, Sendang Biru, South Malang they are called Teluk Semut, Watu Meja, and Waru-waru. Underwater Visual Census (UVC) was used as a method for this research to identify reef fish in a transect of $100 \times 5 \times 5 \mathrm{~m}$ scale in (Length, Width, and Height). Results shows several fishes was used to identify yet the family of Chaetodontidae with mean abundance 8 in Teluk Semut 1 station, 2.25 in Teluk Semut 2 station, 12.5 in Rumah Ikan station, \& 13.5 in Watu Meja station. Watu Meja and Fish Apartment station shows higher mean abundance than other station, this indicates coral reefs ecosystem in this station have a better health \& condition compare to the other stations. Results for family family Haemulidae, Snapper and Grouper shows low mean abundance, that indicates overfishing on Sempu Strait, South Malang. In other cases, the purposes of Reef Check is to determine the extents of human activities and its impact against the distribution and the healthiness of coral reefs in the area. For further extent, there has been still indications toward its management system yet fisheries potential in certain areas for this research.
\end{abstract}

Keywords: Reef Check; Survey; Reef Fisheries; Ecosystem; and Sempu Strait

\begin{abstract}
Abstrak
Salah satu tujuan Reef Check adalah untuk menentukan luasan sebaran dampak aktifitas manusia terhadap sebaran terumbu karang. Pulau Jawa adalah salah satu pulau yang memiliki cukup banyak pantai, terutama di wilayah Jawa Timur perairan yang menjadi titik fokus pada penelitan ini adalah Perairan Selat Sempu, Sendang Biru, Malang Selatan dengan stasiun Teluk Semut, Watu Meja, dan Waru-waru. Metode dalam penelitian ini dalam mengkuantifikasi jumlah ikan dan ukuran ikan adalah Underwater Visual Census (UVC) yaitu mendeskripsikan ikan yang berada didalam transek $100 \times 5 \times 5$ m (panjang, lebar dan tinggi). Hasil pengamatan menunjukkan ikan karang yang paling banyak ditemui adalah ikan famili Chaetodontidae dengan rata-rata kelimpahan 8 pada stasiun Teluk Semut 1, 2.25 pada stasiun Teluk Semut 2, 12.5 pada stasiun Rumah Ikan, \& 13.5 pada stasiun Watu Meja. Stasiun Watu Meja dan Rumah Ikan memiliki nilai terbesar yang mengindikasikan kondisi terumbu karang pada stasiun ini cenderung lebih baik dari stasiun lainnya. Hasil rata-rata kelimpahan ikan famili Haemulidae, Snapper dan Grouper sebagai ikan terget penangkapan menunjukkan nilai yang rendah dengan adanya indikasi aktivitas penangkapan berlebih di perairan Selat Sempu Malang Selatan. Kegiatan monitoring ekosistem terumbu karang perlu dilakukan secara berkelanjutan untuk lebih mengetahui kondisi kesehatan ekosistem terumbu karang. Untuk kedepannya masih perlu adanya tindakan pengelolaan dan pemanfaatan yang lestari, dengan melihat potensi ikan karang pada suatu areal/kawasan terumbu karang.
\end{abstract}

Kata Kunci: Reef Check; Survei; Ekosistem; Ikan Karang; dan Selat Sempu 


\section{Pendahuluan}

Terumbu karang di selatan Jawa Timur tersebar hampir diseluruh perairan laut selatan, dimulai dari kawasan timur yakni Banyuwangi, Jember, Malang, Tulungagung hingga Pacitan yang merupakan kabupaten paling barat (Rahmania, 2016; Luthfi et al., 2016; Luthfi et al., 2016). Tidak semua perairan selatan Jawa dapat ditumbuhi terumbu karang dikarenakan karang sebagai penyusun terumbu karang memerlukan kondisi perairan yang spesifik semisal arus dan gelombang tidak terlalu keras, perairan yang jernih dengan sedikit sedimentasi, tidak ada polutan, kadar nutrient yang rendah dan suhu laut diantara $29-31^{\circ} \mathrm{C}$ (Veron, 2000).

Pratchett et al. (2006) menyatakan bahwa ekosistem terumbu karang akan mempengaruhi keanekaragaman ikan terumbu didalamnya, karena terumbu karang berfungsi sebagai shelter dan lokasi mencari makan. Jumlah ikan terumbu di Indonesia tidak diketahui secara pasti namun diperkirakan terdapat 2057 spesies yang masuk kedalam 113 famili. Family ikan yang sering ditemukan diantaranya adalah Gobiidae (272 species), Labridae (178), Pomacentridae (152), Apogonidae (114), Blenniidae (107), Serranidae (102), Muraenidae (61), Syngnathidae (61),
Chaetodontidae (59), dan Lutjanidae (43) (Allen dan Adrim, 2003).

Eratnya hubungan antara terumbu karang dengan ikan terumbu dapat dilihat pada family Chaetodontidae. Family ikan terumbu Chaetodontidae, yang secara global memiliki 12 genus dan 129 spesies (Froese and Paul, 2012). Ikan ini juga disebut ikan sebagai butterflyfish atau ikan kepe-kepe. Hampir semua family ini memiliki warna cerah dengan ciri ada garis hitam di matanya. Umumnya ikan dari family Chaetodontidae adalah pemakan polip dan tentakel karang, invertebrate kecil, telur ikan dan filamentaous algae (Nelson, 1994.). Berdasarkan pola makannya ikan ini dibagi menjadi 3 yaitu 1 . Obligate coral feeder dimana ikan ini hanya mengkonsumsi karang. 2. Facultative coral feeder yakni apabila ikan ini memakan karang sebagai makanan utama dan terkadang memakan invertebrate yang ada dikarang sebagai makanan tambahan. 3. Non-coral feeder, yakni ikan yang jarang mengkonsumsi karang (Pratchett, 2007). Contoh ikan dari family Chaetodontidae adalah Chaetodon kleinii dan C. trifasciatus. C. kleinii sangat tergantung pada tutupan karang hidup terutama pada karang Acropora dan Pocillopora

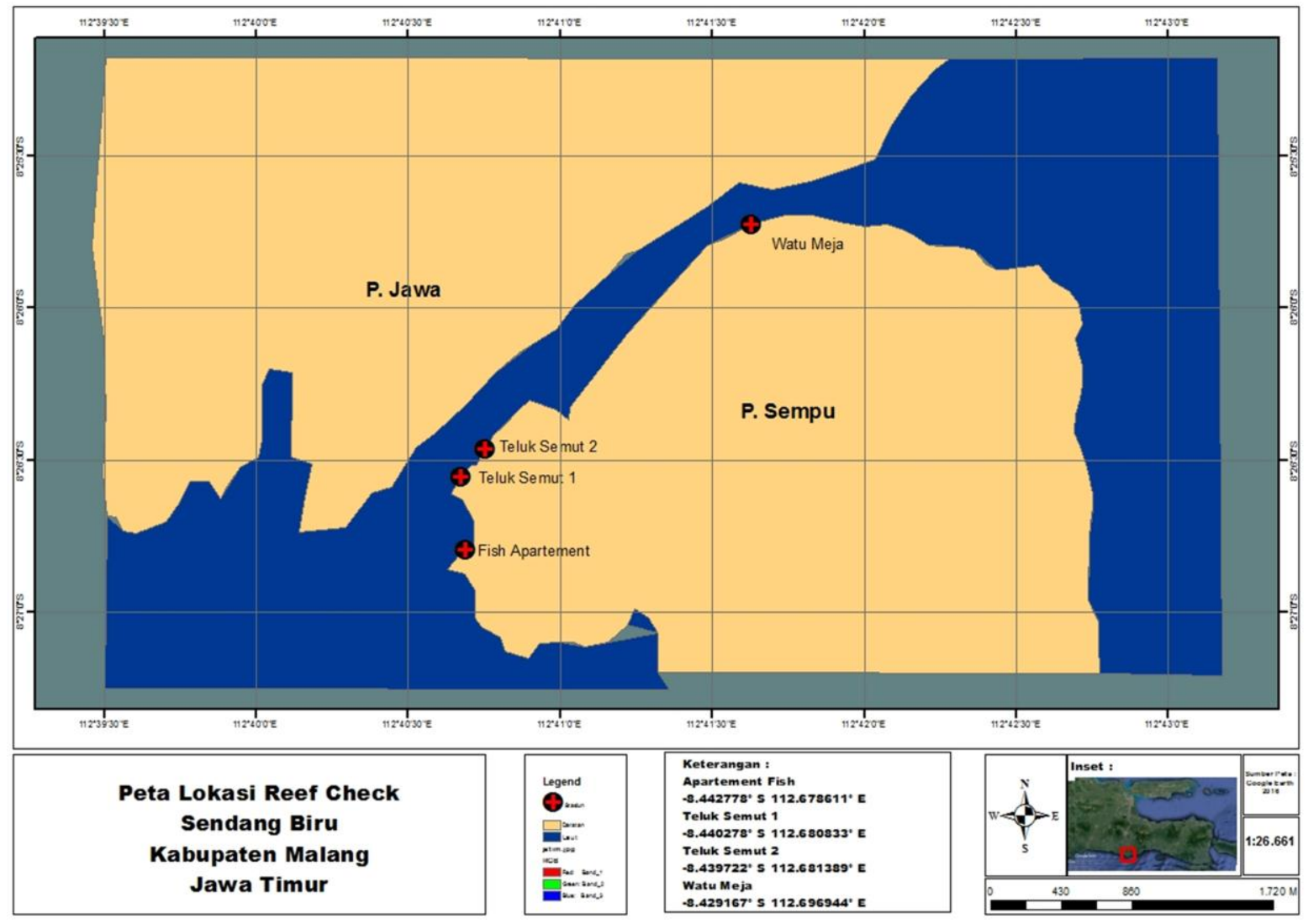

Gambar 1. Lokasi Penelitian di Selat Sempu, Malang 
damicornis, karena ikan jenis obligate feeder (Pratchett et al 2006; Pratchett, 2007). C. trifasciatus memakan banyak karang jenis Acropora, secara spesifik adalah $A$. clathrate yang berbentuk meja dan A. Formosa yang memiliki bentuk pertumbuhan bercabang. Beberapa penelitian juga menunjukkan ikan C. trifasciatus memiliki daerah kekuasaan atau feeding territorial sepanjang 10,56 \pm 2,33 m (Samways, 2005).

Berdasarkan pengamatan dan wawancara dengan nelayan setempat, kegiatan penangkapan ikan ekonomis penting dan ikan indicator di Selat Sempu tampaknya sudah mulai menurun karena memang ukurannnya yang semakin kecil. Sedangkan permintaan pasar ukuran konsumsi untuk kerapu dan ikan kakatua seharusnya $>30 \mathrm{~cm}$. Kegiatan ReefCheck adalah kegiatan monitoring rutin pada ikan terumbu yang telah dilakukan sejak tahun 2015. Tujuan dari penelitian ini adalah untuk mengetahui kelimpahan ikan terumbu baik yang bersifat ekonomis penting maupun sebagai ikan indicator yang berada pada Selat Sempu, Kabupaten Malang.

\section{Metode Penelitian}

\subsection{Waktu dan Tempat}

Pengambilan data dilakukan pada tanggal 16-18 Desember 2016, di Perairan Selat Sempu, Sendang Biru, Kabupaten Malang. Pengamatan dilakukan pada waktu pagi hari di empat titik yaitu: Fish Apartement $\left(-8.442778^{\circ}\right.$ LS dan $\left.112.678611^{\circ} \mathrm{BT}\right)$, Teluk Semut $1\left(-8.440278^{\circ} 112.680833^{\circ}\right)$, Teluk Semut $2\left(-8.439722^{\circ}\right.$ LS dan $112.681389^{\circ}$ BT) dan Watu Meja (-8.429167 ${ }^{\circ}$ LS dan $112.696944^{\circ}$ BT), (Gambar 1).

\subsection{Pengambilan Data Ikan Karang}

Metode untuk mengkuantifikasi jumlah ikan dan ukuran ikan adalah underwater visual census yaitu mendeskripsikan ikan yang berada didalam transek $100 \times 5 \times 5$ m (panjang, lebar dan tinggi). Pengambilan data ikan dan karang dilakukan secara berurutan. Setelah pendataan ikan selesai, selang beberapa menit diikuti pendataan karang (Manuputty, 2006). Dengan pertimbangan waktu dan persediaan oksigen yang terbatas, kegiatan pendataan ikan karang dimulai beberapa menit setelah pemasangan transek. Kelimpahan ikan tiap jenis mulai dihitung dengan batasan jarak pantau 2,5m pada sisi kiri dan kanan transek (English et al., 1997). Identifikasi jenis ikan karang dilakukan secara langsung di lapangan dan menggunakan dokumentasi foto bawah air Canon G16 (Jepang). Ikan-ikan yang sudah dikenali berdasarkan protocol ReefCheck dicatat secara langsung diatas sabak sedangkan beberapa jenis ikan yang belum dikenali nanti akan diidentifikasi merujuk pada Allen (2000); Kuiter and Tonozuka (2001).

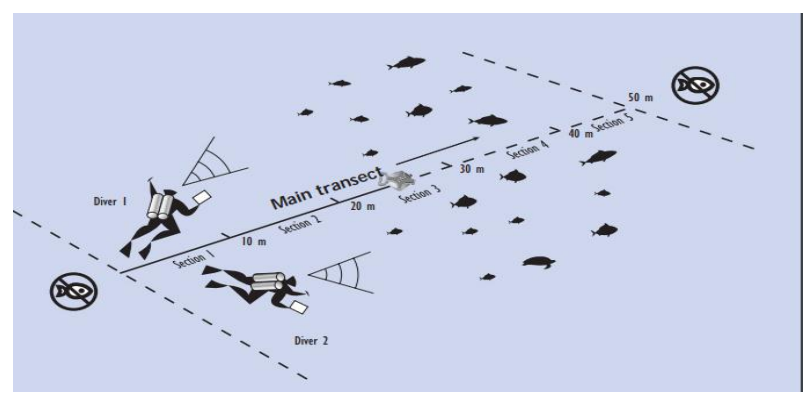

Gambar 2. Ilustrasi metode pengambilan data ikan karang menggunakan underwater visual census (UVC) (Hill and Clive, 2004)

Pengambilan data ikan dilakukan oleh 2 orang penyelam dengan pembagian tugas tiap penyelam yaitu 2,5m di bagian kiri transek dan 2,5m di bagian kanan transek. Perhitungan dan pencatatan jumlah ikan dengan menggunakan sistem turus di sabak (underwater slate) yang sudah dibuat sebelumnya. Pengamatan dilakukan tiap 20m dengan jeda 5m sepanjang 100m (Gambar 2).

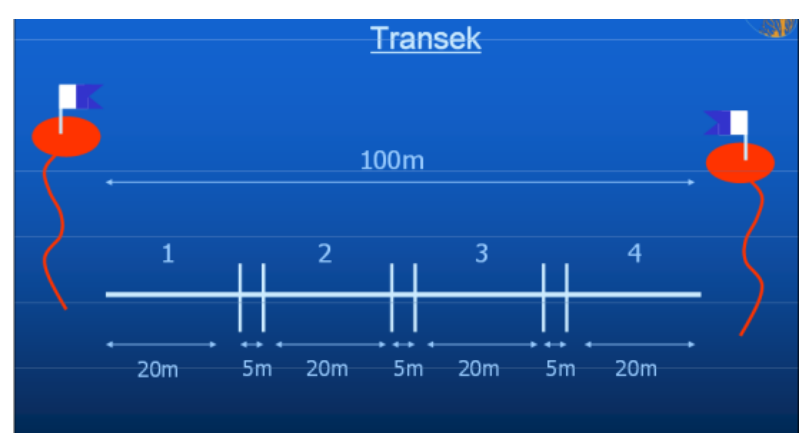

Gambar 3. Transek yang digunakan saat Pengamatan

\subsection{Estimasi Ukuran Ikan Karang}

Pengukuran data ikan dapat dilakukan dengan metode estimasi ukuran ikan karang. Perbedaan dalam menentukan ukuran tidak boleh melebihi $20 \%$ dari ukuran sebenarnya ikan tersebut. Ada banyak faktor yang dapat mempengaruhi pada 
Tabel 1

Data Ikan Karang di stasiun Teluk Semut 1

\begin{tabular}{|c|c|c|c|c|c|c|c|}
\hline \multirow{2}{*}{ Fish } & \multicolumn{4}{|c|}{ Kedalaman } & \multirow{2}{*}{ Total } & \multirow{2}{*}{ Mean } & \multirow{2}{*}{ SD } \\
\hline & $0-20 \mathrm{~m}$ & $25-45 m$ & $50-70 \mathrm{~m}$ & $75-95 \mathrm{~m}$ & & & \\
\hline Butterflyfish & 12 & 12 & 5 & 3 & 32 & 8 & 4.69 \\
\hline Haemulidae & 7 & 1 & 2 & 0 & 10 & 2.5 & 3.109 \\
\hline Snapper & 0 & 2 & 0 & 0 & 2 & 0.5 & 1 \\
\hline Barramundi cod & 0 & 0 & 0 & 0 & 0 & 0 & 0 \\
\hline Humphead wrasse & 0 & 0 & 0 & 0 & 0 & 0 & 0 \\
\hline Bumphead parrot & 0 & 0 & 0 & 0 & 0 & 0 & 0 \\
\hline Parrotfish & 0 & 0 & 0 & 0 & 0 & 0 & 0 \\
\hline Moray eel & 0 & 0 & 0 & 0 & 0 & 0 & 0 \\
\hline \multicolumn{8}{|l|}{ Grouper sizes $(\mathrm{cm})$ : } \\
\hline $30-40 \mathrm{~cm}$ & 0 & 0 & 0 & 0 & 0 & 0 & 0 \\
\hline $40-50 \mathrm{~cm}$ & 0 & 0 & 0 & 0 & 0 & 0 & 0 \\
\hline $50-60 \mathrm{~cm}$ & 0 & 0 & 0 & 0 & 0 & 0 & 0 \\
\hline$>60 \mathrm{~cm}$ & 0 & 0 & 0 & 0 & 0 & 0 & 0 \\
\hline Total \# grouper observed & 0 & 0 & 0 & 0 & 0 & 0 & 0 \\
\hline
\end{tabular}

saat melakukan estimasi pengukuran panjang ikan yaitu objek yang terlihat lebih besar saat menggunakan masker, arah sudut ikan, tingkat kerjenihan perairan dan bentuk dari ikan yang berbeda-beda (English et al., 1997). Metode estimasi ukuran ikan karang pada penelitian ini mengacu pada metode yang diterapkan oleh reef check Indonesia, yaitu perkiraan panjang ikan menggunakan perbandingan under water slate dengan visual pengamatan secara langsung.

Mengestimasi panjang setiap individu ikan yang terlihat di transek atau long swim dengan seakurat mungkin merupakan satu komponen penting dari protokol ini. Data tersebut dibutuhkan untuk mengestimasi biomassa dari famili atau jenis ikan. Untuk itu, sangat penting bagi para pengamat ikan untuk mendapatkan pelatihan yang memadai sehingga mereka dapat mengestimasi panjang ikan secara akurat sambil berenang dalam air. Tingkat keakuratan dari para pengamat ikan harus dicatat pada awal pemantauan sehingga derajat kesalahan (error) dari estimasi mereka dapat diketahui. Idealnya, para pengamat ikan harus dapat mengestimasi panjang ikan dengan selisih $5 \mathrm{~cm}$ dan harus bertujuan mencapai tingkat keakuratan tersebut melalui pelatihan dan praktek. Namun demikian, beberapa pengamat ikan yang berpartisipasi dalam kegiatan pemantauan akan mampu mengestimasi panjang ikan dalam kisaran selisih $10 \mathrm{~cm}$. Kelas-kelas ukuran ikan dibagi ke dalam ikan kecil sampai sedang $(10-35 \mathrm{~cm})$ dan ikan besar $(>35 \mathrm{~cm})$.

\section{Hasil dan Pembahasan}

Hasil pengamatan ikan karang di stasiun Teluk Semut 1 pada kedalaman 4-6m dengan jarak 0-20m 12 Butterflyfish, 7 Haemulidae. Pada jarak 25-45m terdapat 12 Butterflyfish, 1 Haemulidae, 2 Snapper. Pada jarak 50-70m terdapat 5 Butterflyfish, 2 Haemulidae. Pada jarak 79-95m hanya terdapat 3 Butterflyfish. Pada kedalaman ini hanya ditemukan 3 jenis ikan Butterflyfish 32 ekor, Haemulidae 10 ekor dan Snapper 2 ekor. Jenis ikan yang tidak ditemukan pada stasiun Teluk Semut antara lain Moray eel, Parrotfish, Bumphead parrot, Humphead wrasse dan Baramundi COD. Rata-rata kelimpahan ikan pada stasiun Teluk Semut 1 dapat dilihat pada Tabel 1.

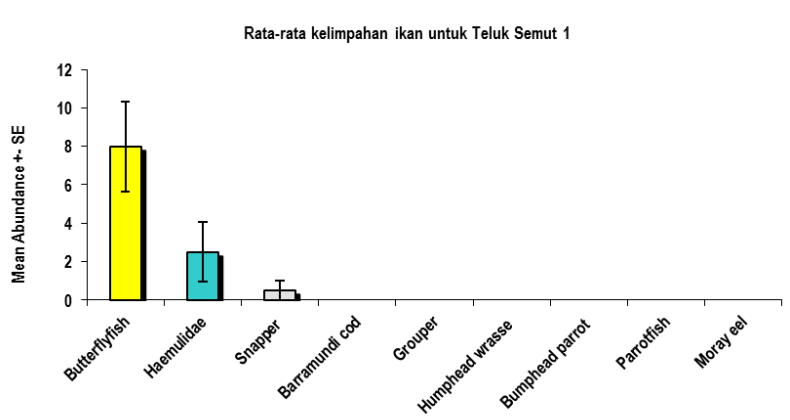

Gambar 3. Grafik Sebaran Ikan Karang di Stasiun Teluk Semut 1

Berdasarkan Gambar 3, dapat diketahui kelimpahan ikan yang ada di stasiun Teluk Semut 1 didominasi jenis ikan Butterflyfish dengan nilai rata-rata 8 . Kelimpahan dengan rata-rata 2.5 jenis ikan Haemulidae, sedangkan jenis ikan Snapper 
Tabel 2

Data Ikan Karang di stasiun Teluk Semut 2

\begin{tabular}{|c|c|c|c|c|c|c|c|}
\hline \multirow{2}{*}{ Fish } & \multicolumn{4}{|c|}{ Kedalaman } & \multirow{2}{*}{ Total } & \multirow{2}{*}{ Mean } & \multirow{2}{*}{ SD } \\
\hline & $0-20 \mathrm{~m}$ & $25-45 m$ & $50-70 \mathrm{~m}$ & $75-95 \mathrm{~m}$ & & & \\
\hline Butterflyfish & 2 & 1 & 5 & 1 & 9 & 2.25 & 1.893 \\
\hline Haemulidae & 0 & 0 & 0 & 1 & 1 & 0.25 & 0.5 \\
\hline Snapper & 0 & 0 & 0 & 0 & 0 & 0 & 0 \\
\hline Barramundi cod & 0 & 0 & 0 & 0 & 0 & 0 & 0 \\
\hline Humphead wrasse & 0 & 0 & 0 & 0 & 0 & 0 & 0 \\
\hline Bumphead parrot & 0 & 0 & 0 & 0 & 0 & 0 & 0 \\
\hline Parrotfish & 0 & 0 & 0 & 0 & 0 & 0 & 0 \\
\hline Moray eel & 0 & 0 & 0 & 0 & 0 & 0 & 0 \\
\hline \multicolumn{8}{|l|}{ Grouper sizes (cm): } \\
\hline $30-40 \mathrm{~cm}$ & 0 & 0 & 0 & 0 & 0 & 0 & 0 \\
\hline $40-50 \mathrm{~cm}$ & 0 & 0 & 0 & 0 & 0 & 0 & 0 \\
\hline $50-60 \mathrm{~cm}$ & 0 & 0 & 0 & 0 & 0 & 0 & 0 \\
\hline$>60 \mathrm{~cm}$ & 0 & 0 & 0 & 0 & 0 & 0 & 0 \\
\hline Total \# grouper observed & 0 & 0 & 0 & 0 & 0 & 0 & 0 \\
\hline
\end{tabular}

nilai rata-rata 0.5. Rata-rata kelimpahan dapat dilihat pada grafik batang Gambar 3.

Stasiun kedua pengambilan data kelimpahan ikan karang di perairan Sendang Biru yaitu stasiun Teluk Semut 2 hasil pengamatan ikan pada kedalaman 4-6m dengan jarak 0-20m 2 Butterflyfish. Pada jarak 25-45m terdapat 1 Butterflyfish. Pada jarak 50-70m terdapat 5 Butterflyfish. Pada jarak 7995m hanya terdapat 1 Butterflyfish, 1 Haemulidae. Pada stasiun Teluk Semut 2 ini hanya ditemukan 2 jenis ikan Butterflyfish 9 ekor, Haemulidae 1 ekor. Rata-rata kelimpahan ikan pada stasiun Teluk Semut 1 dapat dilihat pada Tabel 2.

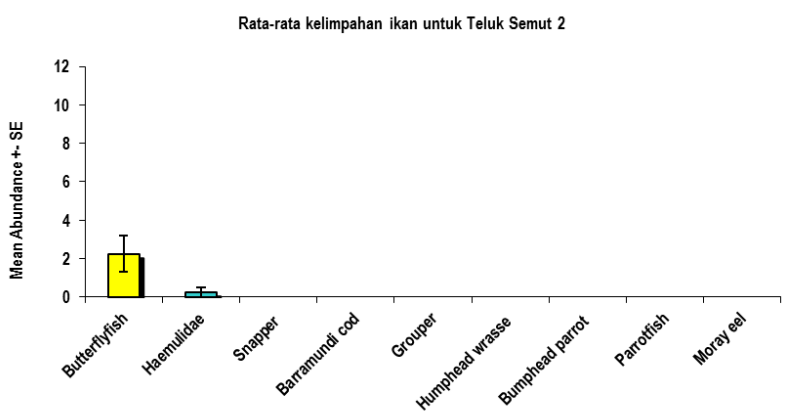

Gambar 4. Grafik Sebaran Ikan Karang di Stasiun Teluk Semut 2

Kelimpahan ikan yang ada di stasiun Teluk Semut 2 hanya ditemukan 2 jenis ikan. Kelimpahan ikan Butterflyfish dengan rata-rata 2, jenis ikan Haemulidae nilai rata-rata kelimpahan 0.5. Jenis ikan yang tidak didapatkan pada stasiun Teluk Semut 2 adalah Snapper, Grouper, Barramundi COD, Humphead wrasse, Bumphead parrot, Parrotfish dan Moray eel (Gambar 4)
Pengamatan di stasiun Rumah Ikan hasil pengamatan ikan karang pada kedalaman 4-6m pada tanggal 17 Desember 2016 dengan jarak 020m terdapat 40 ekor ikan jenis Butterflyfish, 3 ekor ikan jenis Haemulidae, 3 ekor ikan jenis Snapper, 21 ekor ikan jenis Parrotfish, dan 2 ekor ikan jenis Grouper dengan besar 30-40 cm. Pada jarak 25-45m terdapat 8 ekor ikan jenis Butterflyfish, 4 ekor ikan jenis Haemulidae, 4 ekor ikan jenis Parrotfish dan 2 ekor ikan jenis Grouper berukuran 40-50 cm. Pada jarak 50-70m terdapat 2 ekor ikan jenis Butterflyfish, 1 ekor ikan jenis Parrotfish dan 1 jenis Grouper dengan ukuran 50-60 cm. Pada jarak 79-95m tidak ditemukan ikan pada saat pengamatan. Pada kedalaman ini hanya ditemukan 50 ekor jenis ikan Butterflyfish, 7 ekor ikan jenis Haemulidae, 3 ekor ikan jenis Snapper, 26 ekor ikan jenis Parrotfish dan 5 ekor ikan jenis Grouper. Rata-rata kelimpihan ikan pada stasiun Rumah Ikan dapat dilihat pada Tabel 3.

Kelimpahan ikan Chaetodontidae mencerminkan kondisi suatu terumbu karang, jumlah tutupan karang hidup yang tinggi berkorelasi positip dengan jumlah ikan yang ada dalam ekosistem tersebut. Chaetodon unimaculatus banyak memakan polip dari karang berbentuk daun montiporid (Acroporidae) sedangkan Chaetodon ornatissimus dan Chaetodon multicinctus memiliki kesukaan pada jenis karang Porites (Bell and Galzin, 1984). Ratarata kelimpahan ikan karang pada stasiun Rumah Ikan dapat dilihat dari grafik batang pada Gambar 5.

Famili dengan jumlah terbanyak kedua adalah Haemulidae dan Lutjanidae. Ikan karang ini 
Tabel 3

Data Ikan Karang di Stasiun Rumah Ikan

\begin{tabular}{|c|c|c|c|c|c|c|c|}
\hline \multirow{2}{*}{ Fish } & \multicolumn{4}{|c|}{ Kedalaman } & \multirow{2}{*}{ Total } & \multirow{2}{*}{ Mean } & \multirow{2}{*}{ SD } \\
\hline & $0-20 \mathrm{~m}$ & $25-45 m$ & $50-70 \mathrm{~m}$ & $75-95 \mathrm{~m}$ & & & \\
\hline Butterflyfish & 40 & 8 & 2 & 0 & 50 & 12.5 & 18.65 \\
\hline Haemulidae & 3 & 4 & 0 & 0 & 7 & 1.75 & 2.062 \\
\hline Snapper & 3 & 0 & 0 & 0 & 3 & 0.75 & 1.5 \\
\hline Barramundicod & 0 & 0 & 0 & 0 & 0 & 0 & 0 \\
\hline Humphead wrasse & 0 & 0 & 0 & 0 & 0 & 0 & 0 \\
\hline Bumphead parrot & 0 & 0 & 0 & 0 & 0 & 0 & 0 \\
\hline Parrotfish & 21 & 4 & 1 & 0 & 26 & 6.5 & 9.815 \\
\hline Moray eel & 0 & 0 & 0 & 0 & 0 & 0 & 0 \\
\hline \multicolumn{8}{|l|}{ Grouper sizes $(\mathrm{cm}):$} \\
\hline $30-40 \mathrm{~cm}$ & 2 & 0 & 0 & 0 & 2 & 0.5 & 1 \\
\hline $40-50 \mathrm{~cm}$ & 0 & 2 & 0 & 0 & 2 & 0.5 & 1 \\
\hline $50-60 \mathrm{~cm}$ & 0 & 0 & 1 & 0 & 1 & 0.25 & 0.5 \\
\hline$>60 \mathrm{~cm}$ & 0 & 0 & 0 & 0 & 0 & 0 & 0 \\
\hline Total \# grouper observed & 2 & 2 & 1 & 0 & 5 & 1.25 & 0.957 \\
\hline
\end{tabular}

tergolong sebagai ikan target atau ikan konsumsi atau ikan dengan nilai ekonomis. Ikan karang ini yang menjadi target penangkapan oleh nelayan. Semakin banyak ikan jenis ini maka semakin banyak pula hasil tangkapan nelayan dan semakin tinggi pula keuntungan yang diperoleh nelayan. Kondisi ini dapat meningkatkan kesejahteraan nelayan di perairan tersebut. Keberadaan ikan jenis tersebut di perairan Selat Sempu menunjukan perairan ini memiliki potensi perikanan yang baik apabila kondisi perairan terus dijaga dan dirawat, sehingga keberadaan ikan-ikan target semakin melimpah. Ukuran ikan target di Selat Sempu dengan rerata $<50 \mathrm{~cm}$ dimungkinkan adanya tekanan atau bahkan overfishing. Tekanan atau stress dapat dilihat dengan berkurangnya tutupan karang hingga 31,79\% pada tahun 2014 (Luthfi et al., 2015) sehingga ikan target yang bergantung pada terumbu karang mengalami penurunan populasi ataupun ukuran. Overfishing yang terjadi di Fiji juga telah membuat penurunan ukuran dari ikan-ikan terumbu disana (Wilson et al., 2008).

Hasil pengamatan menunjukkan ikan karang yang paling banyak ditemui adalah ikan famili Chaetodontidae. Ikan ini sebagai indikator kondisi terumbu karang suatu perairan, karena sebagian besar siklus hidup mereka di terumbu karang. Ketersediaan makanan Chaetodontidae ada pada terumbu karang (Laikun et al, 2014). Apabila jumlah ikan jenis ini yang melimpah dapat diartikan bahwa kondisi terumbu karang masih baik (Bell dan Galzin, 1984).

Rendahnya jumlah ikan ini di perairan Selat Sempu menunjukan kondisi terumbu karang di perairan ini tidak baik atau telah rusak. Kerusakan terumbu karang dapat disebabkan oleh aktifitas penangkapan yang tinggi di daerah ini. Penyebab lainnya adalah limbah dari aktifitas manusia yang bermukim di dekat perairan. Limbah ini membuat kondisi perairan tercemar dan mengganggu kondisi terumbu karang. Grigg (2004) telah melakukan pengamatan jumlah dan sebaran ikan terumbu di perairan Hawaii di kawasan konservasi dan non-konservasi, terlihat jelas penurunan jumlah ikan terumbu di kawasan nonkonservasi dikarenakan rendahnya kualitas perairan dikarenakan banyak polutan yang masuk didalam perairan tersebut.

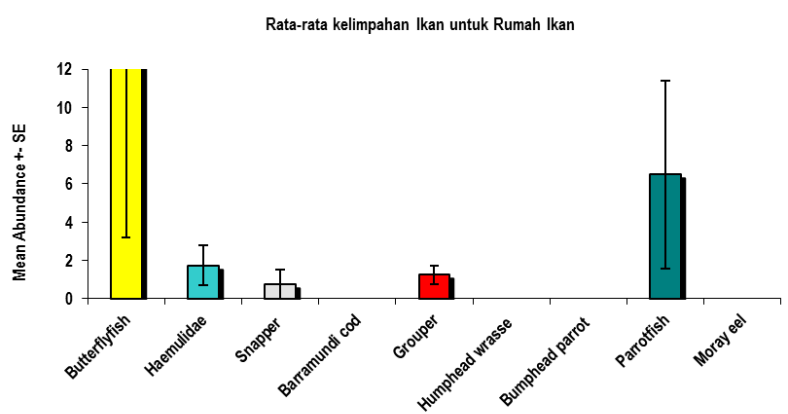

Gambar 5. Grafik Sebaran Ikan Karang di Stasiun Rumah Ikan

Tabel 4 menunjukkan kelimpahan ikan yang ada di stasiun Watu Meja ditemukan berbagai macam jenis ikan. Kelimpahan ikan butterflyfish dengan rata-rata 13.5 pada grafik berwarna kuning, jenis ikan Haemulidae nilai rata-rata kelimpahan 4 . Jenis ikan Snapper kelimpahan rata-rata 0.25, jenis ikan Grouper 1.25, jenis ikan Barramundi COD 0.75, 
Tabel 4

Data Ikan Karang di Stasiun Watu Meja

\begin{tabular}{|c|c|c|c|c|c|c|c|}
\hline \multirow{2}{*}{ Fish } & \multicolumn{4}{|c|}{ Kedalaman } & \multirow{2}{*}{ Total } & \multirow{2}{*}{ Mean } & \multirow{2}{*}{ SD } \\
\hline & $0-20 \mathrm{~m}$ & $25-45 \mathrm{~m}$ & $50-70 \mathrm{~m}$ & 75-95m & & & \\
\hline Butterflyfish & 8 & 29 & 12 & 5 & 54 & 13.5 & 10.72 \\
\hline Haemulidae & 4 & 2 & 7 & 3 & 16 & 4 & 2.16 \\
\hline Snapper & 1 & 0 & 0 & 0 & 1 & 0.25 & 0.5 \\
\hline Barramundi cod & 1 & 2 & 0 & 0 & 3 & 0.75 & 0.957 \\
\hline Humphead wrasse & 0 & 0 & 0 & 0 & 0 & 0 & 0 \\
\hline Bumphead parrot & 1 & 0 & 0 & 0 & 1 & 0.25 & 0.5 \\
\hline Parrotfish & 0 & 0 & 0 & 1 & 1 & 0.25 & 0.5 \\
\hline Moray eel & 0 & 0 & 0 & 0 & 0 & 0 & 0 \\
\hline \multicolumn{8}{|l|}{ Grouper sizes $(\mathrm{cm})$ : } \\
\hline $30-40 \mathrm{~cm}$ & 2 & 0 & 0 & 0 & 2 & 0.5 & 1 \\
\hline $40-50 \mathrm{~cm}$ & 0 & 2 & 0 & 0 & 2 & 0.5 & 1 \\
\hline $50-60 \mathrm{~cm}$ & 0 & 0 & 1 & 0 & 1 & 0.25 & 0.5 \\
\hline$>60 \mathrm{~cm}$ & 0 & 0 & 0 & 0 & 0 & 0 & 0 \\
\hline Total \# grouper observed & 2 & 2 & 1 & 0 & 5 & 1.25 & 0.957 \\
\hline
\end{tabular}

jenis ikan Bumphead parrot 0.25 dan jenis ikan Parrotfish 0.25. Sedangkan jenis ikan yang tidak ditemukan pada pengamatan dilapang antara lain Humphead wrasse dan Moray eel. Rata-rata kelimpahan Dapat dilihat pada grafik batang Gambar 6.

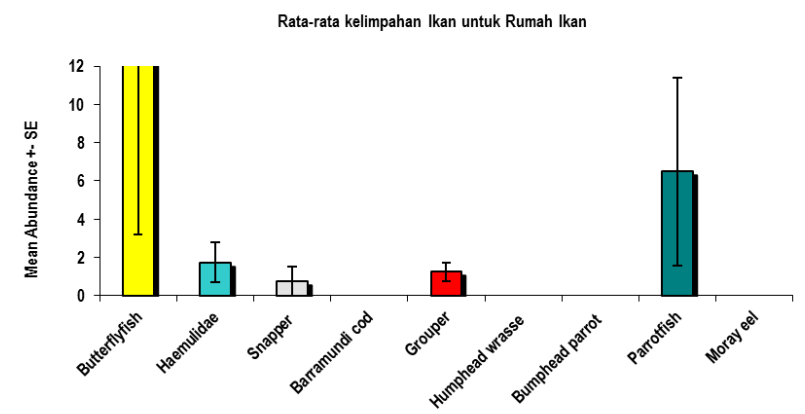

Gambar 6. Grafik Sebaran Ikan Karang di Stasiun Watu Meja

Hasil pengamatan ikan lainnya adalah jenis Scaridae dan Murainidae. Jumlah jenis tersebut lebih sedikit dibandingkan yang lainnya. Jenis scaridae atau jenis pomacentridae termasuk ikan herbivore dan jarang ditemui dengan jumlah individu yang sangat sedikit. Ikan herbivore memiliki peran penting dalam mengontrol pertumbuhan alga bentik di perairan, dari cara pemangsaannya kelompok ini dibagi menjadi browser, grazer, scraper, dan crusher (Ruitton et al., 2000). Berkurangnya alga di daerah terumbu karang akan memberikan kesempatan kepada juvenile karang untuk melakukan okupasi lebih luas, sehingga akan berdampak kepada terjanya tutupan karang hidup secara alamiah.

\section{Simpulan}

Berdasarkan hasil dan pembahasan diatas, dapat disimpulkan beberapa hal berikut :

a. Keberadaan ikan Butterflyfish sebagai indikator kesehatan terumbu karang menunjukkan nilai rata-rata kelimpahan yang rendah pada setiap stasiun pengamatan, menunjukkan kondisi terumbu karang pada Selat Sempu kurang baik atau mengalami kerusakan sebagai akibat dari aktivitas pelabuhan, perikanan, dan aktivitas wisatawan.

b. Rendahnya nilai rata-rata kelimpahan jenis Haemulidae, Snapper dan Grouper sebagai ikan target perikanan menunjukkan telah terjadinya penangkapan berlebih di Selat Sempu.

c. Kondisi kelimpahan ikan di stasiun Rumah Ikan (Fish Apartment) menunjukkan hasil yang paling baik diantara stasiun pengamatan lainnya, hal tersebut karena adanya ekosistem terumbu karang yang dijaga keberlangsungannya.

Kelimpahan ikan di suatu perairan dipengaruhi oleh ekosistem terumbu karang dan kondisi perairan di kawasan Selat Sempu. Lokasi Selat Sempu yang berdekatan dengan Tempat Pelelangan Ikan (TPI Sendang Biru) yang aktif, akan sangat berdampak pada ekosistem di sekitar Selat Sempu. Kegiatan monitoring ekosistem terumbu karang perlu dilakukan secara berkelanjutan untuk lebih mengetahui kondisi kesehatan ekosistem terumbu karang. Pembuatan 
ekosistem terumbu buatan seperti (fish apartment) diharapkan mampu meningkatkan kondisi kesehatan terumbu karang dengan tetap memperhatikan jalur lalu-lintas kapal.

\section{Ucapan terimakasih}

Terimakasih kami ucapakan yang sebesarbesarnya kepada dosen pembimbing dan temanteman mahasiswa Selam Keahlian yang telah membantu selama proses pengambilan data lapang hingga pembuatan tulisan ini dan kepada semua pihak yang telah banyak menuangkan ide dalam penuliasan ini.

\section{Daftar Pustaka}

Allen, G. R., \& Adrim, M. (2003). Coral reef fishes of Indonesia. Zoological Studies, 42(1), 1-72.

Bell, J. D., \& Galzin, R. (1984). Influence of live coral cover on coral-reef fish communities. Marine Ecology Progress Series, 15(3), 265-274.

English, S., Wilkinson, C., \& Baker, V. (1997). Survey Manual For Tropical Marine Resources. (2 ${ }^{\text {nd }}$ ed). Townsville, Australia: Australian Institute of Marine Science

Froese, R., \& Pauly, D. (2012). FishBase. http://www.fishbase.org. World wide web electronic publication.

Grigg, R. W. (1994). Effects of sewage discharge, fishing pressure and habitat complexity on coral ecosystems and reef fishes in Hawaii. Marine ecology progress series. Oldendorf, 103(1), 25-34.

Hill, J., \& Wilkinson, C. L. I. V. E. (2004). Method For Ecological Monitoring of Coral Reefs. (Ver. 1). Townsville, Australia: Australian Institute of Marine Science.

Hodgson, G., Hill, J., Kiene, W., Maun, L., Mihaly, J., Liebeler, J., Shuman, C. and Torres. (2006). Reef Check Instruction Manual: A Guide to Reef Check Coral Reef Monitoring. California, USA: Reef Check Foundation, Pacific Palisades.

Laikun, J., Rondonuwu, A. B., \& Rembet, U. N. (2015). Kondisi ikan karang famili chaetodontidae di daerah perlindungan laut Desa Bahoi Kecamatan Likupang Barat Kabupaten Minahasa Utara. Jurnal Ilmiah Platax, 2(3), 92-98.

Lowe, R.H., McConnel. (1987). Ecological Studies in Tropical Fish Communitues. Cambridge: Cambridge University Press. P. 382.

Luthfi, O. M., Nurmalasari, N., \& Jauhari, A. (2015). Growth Rate of Staghorn Coral (Acropora) on Coral
Garden Program at Sempu Nature Reserve Malang. Research Journal of Life Science, 2(3), 152-160.

Luthfi, O. M., Isdianto, A., \& Sari, E. J. (2016). Dominance of Acroporids Coral in Coral Reef of Bali Strait, Indonesia. The 6th Annual BaSIC Science 2016. pp. $173-178$

Luthfi, O. M., Pujarahayu, P., Wahyudiarto, A., Fakri, S. R., Sofyan, M., Ramadhan, F., Murian, S., Tovani, I., Mahmud, M., Adi, D. \& Abdi, F., (2016). Biodiversitas dan Populasi Ikan Karang Di Perairan Selat Sempu Sendang Biru Kabupaten Malang Jawa Timur. Jurnal Kelautan: Indonesian Journal of Marine Science and Technology, 9(1), 43-49.

Malikusworo, H. (1986). Coral Reef Community. In Training Course in Coral Reef Research Methods and Management. March 25 - April 30. Bogor. Indonesia. Seameo-Biotrop. pp. $54-58$.

Nelson, J.S. (1994). Fishes of the world. Third edition. New York, USA: John Wiley \& Sons, Inc., 600 p.

Odum, E. P. (1983). Basic ecology. New York, USA: Saunders College Publishing. 612 pp.

Pratchett, M. S., S. K. Wilson, and A. H. Baird. (2006). Declines in the abundance of Chaetodon butterflyfishes following extensive coral depletion. Journal of Fish Biology, 69(5), 1269-1280.

Pratchett, M. S. (2007). Dietary selection by coral-feeding butterflyfishes (Chaetodontidae) on the Great Barrier Reef, Australia. Raffles Bull Zool, 14, 171-176.

Rahmania, N. A. (2016). Transplantasi terumbu karang menggunakan metode conblok di wilayah perairan Pulau Pramuka Balai Taman Nasional Kepulauan Seribu DKI Jakarta. Laporan PKL (tidak dipublikasikan). Surabaya, Indonesia: Fakultas Kelautan dan Perikanan Universitas Airlangga.

Ruitton, S., Francour, P., \& Boudouresque, C. F. (2000). Relationships between algae, benthic herbivorous invertebrates and fishes in rocky sublittoral communities of a temperate sea (Mediterranean). Estuarine, Coastal and Shelf Science, 50(2), 217-230.

Samways, M. J. (2005). Breakdown of butterflyfish (Chaetodontidae) territories associated with the onset of a mass coral bleaching event. Aquatic Conservation: Marine and Freshwater Ecosystems, 15(S1), S101-S107.

Westneat, M. W., Alfaro, M. E., Wainwright, P. C., Bellwood, D. R., Grubich, J. R., Fessler, J. L., Clements, K. D. and Smith, L. L. (2005). Local phylogenetic divergence and global evolutionary convergence of skull function in reef fishes of the family Labridae. Proceedings of the Royal Society of London B: Biological Sciences, 272(1567), pp.993-1000.

Wilson, S. K., Fisher, R., Pratchett, M. S., Graham, N. A. J., Dulvy, N. K., Turner, R. A., Cakacaka, A., Polunin, 
N. V. C., \& Rushton, S. P. (2008). Exploitation and habitat degradation as agents of change within coral reef fish communities. Global Change Biology, 14(12), 2796-2809.
Veron, J.E.N. (2000). Corals of the World. (vol. 1-3). Townsville, Australia: Australian Institute of Marine Science.

(C) 2017 by the authors; licensee Udayana University, Indonesia. This article is an open access article distributed under the terms and conditions of the Creative Commons Attribution license (http://creativecommons.org/licenses/by/3.0/). 